areas such as environmental and public health that match the noneconomic aspirations of modern Japan. And it has demonstrably failed to impart Japan's government with the scientific know-how it needs if it is to assert badly needed regional leadership in Asia, on issues ranging from bird flu and global warming to the construction of large research facilities.

Unsurprisingly, none of this came up during the election campaign: Japanese politics rarely revolves around 'issues', in the Western sense. This time round, Koizumi's plans to reform the post office the world's largest financial institution - were an exception to that rule. Politicians normally confine themselves to securing spending in the districts that they represent. Career civil servants, meanwhile, are systematically rotated between positions every two years and are sometimes more concerned with avoiding culpability than achieving results.

Scientific research has been popular with both politicians and bureaucrats primarily as a form of local spending, and it has been generously supported. Yet little thought has been given to its governance. This is one reason why Japan's scientific achievements are still falling some way short of its aspirations.

Too often, Japanese policy on important scientific issues is hammered out in back rooms. A public hearing is then held and a decision made. Outcomes are rarely clear-cut, and no one takes responsibility for implementing them. In the case of human embryonic stem-cell research, for example, researchers were told that they had the right to do it, but were so obstructed by red tape that little research has actually been done.

What could a genuinely reformist government do? It could start at the grass-roots of science, in the universities, and make it a priority for them to open up both junior positions and tenured ones to young researchers, as well as to women and foreigners. It could introduce evaluation systems that encourage creativity instead of rewarding longevity. Some long-overdue changes at the universities, implemented last year, will have only a marginal impact on these issues.

The government should create an office, akin to the US Office of Research Integrity, to police scientific conduct. It should strengthen the Science Council of Japan, which advises the prime minister, and the Council for Science and Technology Policy, which influences the science budget, so the nation can develop a science policy worthy of its size and economic clout. It could fill some rank-andfile bureaucracy positions with scientists or former scientists, opening up a career path for
"Japan could use scientific collaboration to improve relations with its neighbours, including China and South Korea." struggling postdoctoral students. Currently the science ministry, the patent office and the main science funding agencies are all woefully short of staff with specialist knowledge.

Japan could then prepare itself to fill the leadership void in the Asia-Pacific region with regard to issues such as bird flu and global warming. It could then use scientific collaboration to improve relations with its neighbours, including China and South Korea.

There is little indication that Koizumi will do any of this. For as long as his government instead maintains its lukewarm embrace of science, Japan will continue to punch below its weight in terms of both scientific output and policy leadership in the region.

\section{Do or die for design}

\section{A critical court case is addressing the teaching of 'intelligent design' in American schools.}

T his week, a federal court in Harrisburg, Pennsylvania, began hearing arguments about whether a school can promote intelligent design in the classroom (see page 607). A lawsuit brought by 11 parents of students in the Dover school district alleges that the local school board is violating the constitutional separation of church and state by requiring a statement promoting intelligent design to be read before teachers begin lessons on evolution.

Over the past few years, many scientists have worked hard to discredit intelligent design - but a favourable court verdict could damage the idea more than any amount of academic condemnation. For intelligent design was itself designed, in large part, to get around earlier court decisions that barred creationism from the classroom.

The first such ruling, by the Supreme Court in 1987, overturned a Louisiana law mandating that 'creation science', which sought to verify biblical creation through scientific enquiry, be taught alongside evolution. The second was a 1992 Arkansas finding that its very teaching violated the separation of church and state.

Intelligent design is a vaguer concept than creation science, and deliberately so. It posits only that an intelligent creator shaped the course of evolution. The general idea has been discussed by theologians since Darwin's time, but it was only after these court rulings that it gained a significant following in the United States.

Unlike creation science, intelligent design is not affiliated with any specific religion. Rather than trying to prove its own explanation of the origin of species, it aims to punch holes in scientific doctrine. Its supporters, many of them fundamentalist Christians, have been hoping all along that the concept is sufficiently secular for the courts to permit its teaching in public schools.

If these hopes are realized, and the court rules in favour of the Dover school board, the movement is likely to spread quickly into many school districts. Political support for intelligent design, which has thus far been muted, would probably expand (see Nature 436, 753; 2005).

"If the court rules in favour of the Dover school board, 'intelligent design' is likely to spread quickly into many school districts."

But if the court rules in favour of the plaintiffs, this will seriously undermine efforts to get intelligent design into the classroom. What's more, Christian fundamentalists - some of whom are put off by intelligent design's ecumenical flavour - might then be inclined to abandon it for old-fashioned creationism.

Scientific organizations are well aware of this case's significance, and many have lent public support to the plaintiffs. A ruling in their favour will be welcomed not just by scientists and teachers but by American parents, whose children need to be protected from an injection of superstition into science teaching. 